http://dx.doi.org/10.11646/phytotaxa.164.2.1

\title{
Taxonomy of a monotypic genus Indopiptadenia (Leguminosae-Mimosoideae)
}

\author{
OMESH BAJPAI ${ }^{1}$, AWADHESH K. SRIVASTAVA ${ }^{2}$, ARUN K. KUSHWAHA ${ }^{3} \&$ LAL BABU CHAUDHARY $^{4 *}$ \\ ${ }^{1}$ Plant Diversity, Systematics and Herbarium Division, CSIR-National Botanical Research Institute, Lucknow-226 001, India. \\ E-mail: omeshbajpai@gmail.com \\ ${ }^{2}$ Plant Diversity, Systematics and Herbarium Division, CSIR-National Botanical Research Institute, Lucknow-226 001, India. \\ E-mail: aanshul84@rediffmail.com \\ ${ }^{3}$ Plant Diversity, Systematics and Herbarium Division, CSIR-National Botanical Research Institute, Lucknow-226 001, India. \\ E-mail: akushwaha072@gmail.com \\ ${ }^{4}$ Plant Diversity, Systematics and Herbarium Division, CSIR-National Botanical Research Institute, Lucknow-226 001, India. \\ E-mail:dr_lbchaudhary@rediffmail.com \\ * Corresponding author
}

\begin{abstract}
Indopiptadenia, a monospecific genus with the species I. oudhensis, is confined to the Indo-Nepal border area in scattered populations along the Himalayan foothills between 156-908 m elevation. I. oudhensis has been little studied since its discovery in 1874 . The taxonomy of the genus is reexamined here with extensive notes on diversity, distribution, phenology, ecology and conservation status based on exhaustive field survey and examination of herbarium specimens. A full description including data on many new characters and encompassing all morphological variations is provided to better characterize the species so that its correct systematic position can be ascertained and provide the basis for proper conservation strategies. Placed in the tribe Mimoseae, the species shows more affinity towards the Newtonia group than the Piptadenia group. However, it differs from the former in having unarmed to armed stem, uni- or bijugate leaflets, absence of stemonozone and pods that dehisce generally by rupturing of the pod valves over the seed chambers to leave a persistent replum. The IUCN category Near Threatened (NT) is assigned to the taxon.
\end{abstract}

Key words: South Asia, endemic, Mimoseae, Indopiptadenia oudhensis, Near Threatened

\section{Introduction}

Indopiptadenia Brenan (1955: 178), is a monotypic genus with the species Indopiptadenia oudhensis (Brandis [1874: 168]) Brenan (1955: 178) and is placed in the subfamily Mimosoideae, family Leguminosae (Brenan 1955; Hutchinson 1964; Lewis \& Elias 1981; Sanjappa 1992; Kumar \& Sane 2003; Luckow 2005). I. oudhensis is endemic to the Terai region of the Indo-Nepal border area in the Bhabar zone along the Himalayan foothills in tropical moist deciduous forest (Champion \& Seth 1968). Biswas \& Chandra (1997) and Prakash et al. (2009) have incorrectly suggested that the genus Indopiptadenia is found in America and Africa.

I. oudhensis is a striking evergreen small to medium sized tree with upright branches and profuse pendulous branchlets and leaves. Recent surveys (Kashyap 2009; Prakash et al. 2009; Singh 2010) in India claim that during the last more than 100 years the population of the trees has substantially decreased due to exploitation by local people, habitat destruction and low regeneration ability of the species in natural habitats, and that as a result the species has become rare and threatened.

During the course of study over the last 5 years for the tree flora of Uttar Pradesh, India, the authors have regularly visited different forest areas where they discovered populations of I. oudhensis in the forest of Balrampur district adjacent to the Nepal border. The plants were also discovered in the adjacent area within Nepal in Dang district. Subsequently, the species was found in additional localities in Champawat district of Kumaun region in Uttarakhand State in India. After studying the available information (Duthie 1903, 1906; Biswas \& Chandra 1997; Prakash et al. 2009) it was realized that although the species was discovered more than 100 years ago, it has been 
1900, Inayat 23635(b) \& 23638 (DD); Foot of Nepal Hills, 20 July 1911, R. S. Trouffs 3076 (DD); Barawa, 13 April 1916, Shees Ram 889 (DD); Sohelwa Wildlife Sanctuary: Jarwa forest, 6 km before Nepal border, Near Nalah, $162 \mathrm{~m}, \mathrm{~N} 27^{\circ} 40.365^{\prime} \mathrm{E} 82^{\circ} 31.795^{\prime}, 06$ November 2011, L. B. Chaudhary \& R. Tiwari 263775 (LWG); 167 $\mathrm{m}, \mathrm{N} 27^{\circ} 40.378^{\prime}$ E $82^{\circ} 31.787^{\prime}, 06$ November 2011, L. B. Chaudhary \& R. Tiwari 263776 (LWG); $1 \mathrm{~km}$ before Koylabas from Jarwa, $171 \mathrm{~m}, \mathrm{~N} 27^{\circ} 40.814^{\prime}$ E $82^{\circ} 31.580^{\prime}, 10$ May 2012, L. B. Chaudhary \& O. Bajpai 252716 \& 252717 (LWG); 156 m, N 27 40.354' E 82 31.810', 08 February 2013, O. Bajpai, A. K. Srivastava \& A. Kumar 264426 (LWG); 176 m, N 27 40.831' E 82 31.577', 10 February 2013, O. Bajpai, A. K. Srivastava \& A. Kumar 264432 (LWG); $1.5 \mathrm{~km}$ before Koylabas from Jarwa, $160 \mathrm{~m}, \mathrm{~N} 27^{\circ} 40.362^{\prime} \mathrm{E} 82^{\circ} 31.802^{\prime}, 19$ March 2013, $O$. Bajpai \& L. B. Chaudhary 264439 (LWG); $1.5 \mathrm{~km}$ before Nepal from Tulsipur, inside the river, $176 \mathrm{~m}, \mathrm{~N} 27^{\circ}$ 40.831' E 82 31.577', 20 March 2013, O. Bajpai \& L. B. Chaudhary 264442 (LWG); $1 \mathrm{~km}$ before Koylabas from Jarwa, $160 \mathrm{~m}, \mathrm{~N} 27^{\circ} 40.362^{\prime}$ E $82^{\circ} 31.802^{\prime}, 07$ April 2013, O. Bajpai \& L. B. Chaudhary 264481 \& 264482 (LWG); $165 \mathrm{~m}, \mathrm{~N} 27^{\circ} 40.371^{\prime} \mathrm{E} 82^{\circ} 31.774^{\prime}, 01$ May 2013, O. Bajpai \& L. B. Chaudhary $264497 \& 264498$ (LWG); $165 \mathrm{~m}$, N 27 40.371' E 82 31.774', 30 July 2013, O. Bajpai, A. K. Srivastava \& A. Kumar 263925, 263927 \& 263928 (LWG); Bahraich Dist., Bhachkae, 20 May 1920, Sri Ram s. n. (DD); Saharanpur, Botanic Garden, 02 May 1914, R. N. Parker 6758- from cultivated plant (DD). Uttarakhand: Kumaun: E. Kumaun, $1200 \mathrm{ft}$., May 1883, A. F. Brown s. n. (DD); Sarda Valley, 12 miles above Tanakpur, R. H. Blutter 7235 (DD); Champawat Dist.: on way to Purnagiri, 800 m., March 1990, K. S. Negi 303 (BSD); about $15 \mathrm{~km}$ away from Tanakpur towards Purnagiri, $343 \mathrm{~m}$, N 290 07.545' E 8009.550', 18 August 2013, L. B. Chaudhary, O. Bajpai \& A. Kumar 263952 (LWG); 406 m, N $29^{\circ} 07.739^{\prime} \mathrm{E} 80^{\circ} 09.375^{\prime}, 18$ August 2013, L. B. Chaudhary, O. Bajpai \& A. Kumar 263953 \& 263954 (LWG); 5 km before Sukhi Dang from Tanakpur, 908 m, N 290 08.514' E 80 04.767', 18 August 2013, L. B. Chaudhary, $O$. Bajpai \& A. Kumar 263956 (LWG); Dehra Dun: New Forest, 23 May 1935, M. B. Raizada 69269-from cultivated plant (DD); 23 May 1935, M. B. Raizada 69270- from cultivated plant (DD); 28 May 1937, M. B. Raizada 74553from cultivated plant (DD); May 1939, M. B. Raizada 80086- from cultivated plant (DD); FRI, Arboratum compound 4, Gasthigarni 8110- from cultivated plant (DD).

NEPAL. Western Nepal: Jalesain nala, 29 April 1900, Inayat 23636 (DD); Sunpathri nala, 04 May 1900, Inayat 23637 (DD); Mandaura nala, 2 May 1900, G. H. Inayat 23637(a) (DD, K photo); Barahmdeo, Sarda Gorga, 2000 ft., 2 March 1914, J. H. Lyall 10208 (DD); Bhaunala to Garbha Doti Dist., 13 April 1929, Shees Ram 236 (DD); Bardia Dist., Babai-Deurrali, 351 m, N 28 20.934' E 81 42.226', 23 January 2001, K. K. Shreshtha et al. 666 (TUCH); Kanchanpur Dist., 250 m, 9 August 1980, K. R. Rajbhandari, P.M. Regmi \& K. J. Malla 5153 (KATH); Dang Dist., 179 m, N 27 41.219' E 82 31.651', 31 July 2013, O. Bajpai, A. K. Srivastava \& A. Kumar 263935 (LWG); Dang Dist., 186 m, N 27041.112' E 82 31.622', 31 July 2013, O. Bajpai, A. K. Srivastava \& A. Kumar 263936 (LWG).

\section{Acknowledgements}

The authors are thankful to Dr. C. S. Nautiyal, Director, CSIR-National Botanical Research Institute, Lucknow, India for facilities and the Department of Science \& Technology, Government of India, New Delhi for financial support. We are also grateful to Dr. V. Sampath Kumar, IBLO, Herbarium, Roy. Bot. Gard. Kew, England, UK, Dr. P. Lakshminarasimhan and Dr. Subir Bandopadhyay, Botanical Survey of India, Kolkata, India, Prof. Mohan Siwakoti, Central Dept. of Botany, Tribhuvan University, Kathmandu, Nepal and Mr. Ganga D. Bhatt, National Herbarium and Plant Laboratories, Lalitpur, Kathmandu, Nepal for providing necessary literature and information on the species. The curators of herbaria mentioned in the work are also duly acknowledged for granting permission for herbarium consultation. We thank the editor of the paper Ruth P. Clark, Herbarium, Royal Botanic Gardens, Kew and unknown reviewers for the critical revision of the manuscript and useful comments and suggestions.

\section{References}

Bachman, S., Moat, J., Hill, A., de la Torre, J. \& Scott B. (2011) Supporting Red List threat assessments with GeoCAT: geospatial conservation assessment tool. In: Smith V, Penev L (Eds) e-Infrastructures for data publishing in biodiversity science. ZooKeys 150: 117-126. (Version BETA). GeoCAT tool available from: http://geocat.kew.org/ (accessed 1 April 2014) 
http://dx.doi.org/10.3897/zookeys.150.2109

Bajpai, O., Kumar, A., Mishra, A.K., Sahu, N., Pandey, J., Behera, S.K. \& Chaudhary, L.B. (2012) Recongregation of Tree Species of Katerniaghat Wildlife Sanctuary, Uttar Pradesh, India. Journal of Biodiversity and Environmental Sciences 2(12): 24-40.

Baker, J.G. (1879) Leguminosae. In: Hooker, J.D. ed. Flora of British India. L. Reeve \& Co., London, U.K., 2: 289.

Bentham, G. (1840) Contribution towards a Flora of South America.- Enumeration of Plants collected by Mr Schomburgh in British Guina. Journal of Botany 2: 127-146.

Biswas, S. \& Chandra, S. (1997) Indopiptadenia oudhensis (Brandis) Brenan - An Endangered Tree Legume of Uttar Pradesh and Nepal. Indian Forester 123(5): 419-421.

Brandis, D. (1874) The Forest Flora of North West \& Central India. W.H. Allen and Co., London, U.K., pp. $168-169$.

Brandis, D. (1906) Indian Trees. Archibald Constable \& Co. Ltd., London, U.K., pp. 261.

Brenan, J.P.M. (1955) Notes on Mimosoideae. Kew Bulletin 10(2): 178-179. http://dx.doi.org/10.2307/4108864

Bronn, H.G. (1822) De formis plantarum leguminosarum: primitivis et derivates. Heidelberg, $140 \mathrm{pp}$.

Catalogue of Life: 25th June 2013. Available from: <http://www.catalogueoflife.org/col/details/species/id/11483003> (Accessed: 25 June 2013).

Champion, H.G. \& Seth, S.K. (1968) A Revised Survey of the Forest Types of India. Publication Division, Govt. of India, New Delhi, 404 pp.

Duthie, J.F. (1903) Flora of the Upper Gangetic Plain and of the Adjacent Siwalik and Sub-Himalayan tracts. Superintendent of Government Printing, Calcutta, India, 1: 308. http://dx.doi.org/10.5962/bhl.title.10981

Duthie, J.F. (1906) Piptadenia oudhensis Brandis. In King, G., Duthie, J.F. \& Prain, D. eds. A second century of new and rare Indian plants. Annals of Royal Botanical Garden Calcutta 9: 33, t. 43.

Goyal, A.K. (2009) Collection of Indopiptadenia oudhensis prohibited. Biodiversity News 1(1): 7.

Henry, A.N. \& Roy, B. (1968) Nomenclatural Notes on Indian Flowering Plants. Bulletin of Botanical Survey of India 10: 275.

Herbarium Catalogue, Royal Botanic Gardens, Kew (2006). Published on the internet: http://apps.kew.org/herbcat/ gotoHomePage.do (Accessed: 25 September 2013).

Hutchinson, J. (1964) The genera of flowering plants. Clarendon Press, Oxford, U.K., 1: 154.

IUCN Standards and Petitions Subcommittee. 2013. Guidelines for Using the IUCN Red List Categories and Criteria. Version 10.1. Prepared by the Standards and Petitions Subcommittee. Downloadable from: http://www.iucnredlist.org/documents/ RedListGuidelines.pdf. (Accessed: on 29 January 2014).

Jussieu, A.H.L. (1830) Memoire sur Le Group des Meliacees. Mémoires du Muséum d'Histoire Naturelle 19: 153-304.

Kanjilal, P.C. (1933) A Forest Flora of Pilibhit, Oudh, Gorakhpur \& Bundelkhand. Narendra Publishing House, Delhi, India, pp. 161.

Kashyap, A.K. (2009) Hathipaula ki Talash. Biodiversity News 1(1): 15-16 (in Hindi).

Kumar, S. \& Sane, P.V. (2003) Legumes of South Asia - A checklist. R.B.G., Kew, U.K., pp. 118.

Kurz, W.S. (1871) On Some New or Imperfectly Known Indian Plants. Journal of the Asiatic Society of Bengal. Natural History 40(2): 45-78.

Lamarck, J. B. A. P. de Monnet de (1786) Encyclopédie Méthodique, Botanique 2. Paris, 774 pp.

Lewis, G.P. \& Elias, T.S. (1981) Mimoseae. In: Polhill, R.M. \& Raven, P.H. eds. Advances in Legume Systematics. Royal Botanic Gardens, Kew, U.K., 1: 155-168.

Linneaus, C. (1753) Species Plantarum $1 \& 2$. Stockholm, 1200 pp.

Linnaeus, C. (1759) Systema Naturae, Ed. 10, 2. Stockholm, pp. 825-1384.

Linnaeus, C. (1771) Mantissa Plantarum 2. Stockholm, 587 pp.

Linnaeus, C. f. (1782) Supplementum Plantarum. Brunsvigae, 468 pp.

Luckow, M. (2005) Tribe Mimoseae. In: Lewis, G., Schrire, B., Mackinder, B. \& Lock, M. eds. Legumes of the World. Royal Botanic Gardens, Kew, U.K., pp. 163-183.

Müller, A.J. (1865) Euphorbiaceae. Linnaea 34(1): 1-224.

Ohashi, H. (1979) Mimosaceae. In: Hara, H., William, T.S. \& William, L.H.J. eds. Enumeration of Flowering Plants of Nepal. British Museum, U.K., 2: 123.

Panigrahi, G., Singh, A.N. \& Misra, O.P. (1969) Contribution to the Botany of the Tarai Forests of the Bahraich District of Uttar Pradesh. Bulletin of Botanical Survey of India 11(1\&2): 89-114.

Planchon, J.E. (1848) Sur Les Ulmacees. Annales des Sciences Naturelles; Botanique (sér. 3) 10: 244-341.

Prakash, A., Rawat, K.K. \& Verma, P.C. (2009) Indopiptadenia oudhensis (Brandis) Brenan: monotypic, endemic and highly endangered taxa need conservation in Uttar Pradesh. Biodiversity News 1(1): 2-5.

Rana, T.S. \& Ranade, S.A. (2009) The enigma of monotypic taxa and their taxonomic implications. Current Science 96 (2): 219-229.

Roxburgh, W. (1795) Plants of the coast of Coromandel :selected from drawings and descriptions presented to the hon. court of directors of the East India Company, W. Bulmer and Co. for G. Nicol, Londan, 68 pp. +100 pls.

http://dx.doi.org/10.5962/bhl.title.467

Roxburgh, W. (1819) Plants of the Coast of Coromandel 3. London, 96 pp. +300 pls. 
Saini, D.C. (2005a) Flora of Bahraich District, Uttar Pradesh I-IV. Journal of Economic and Taxonomic Botany 29(3): $528-636$.

Saini, D.C. (2005b) Flora of Bahraich District, Uttar Pradesh V-VI. Journal of Economic and Taxonomic Botany 29(4): 843920.

Sanjappa, M. (1992) Legumes of India. Bishen Singh Mahendra Pal Singh, Dehra Dun, pp. 66.

Singh, G. (2010) Indopiptadenia oudhensis: A plant of Sohelwa Wildlife Forest Division, Balrampur, Uttar Pradesh. National Conference on Biodiversity, Development and Poverty Allevation. Uttar Pradesh Biodiversity Board, Lucknow, pp. 145146. <www.upsbdb.org/pdf/Souvenir2010/35.pdf>.

Singh, K.K. (1997) Flora of Dudhwa National Park. Bishen Singh Mahendra Pal Singh, Dehradun. India, 516 pp.

Smith, J.E. (1806) Exotic Botany: R. Taylor and Co., Londan, U.K., 2: 122.

Smith, J.E. (1810) Ficus. The cyclopædia; or, Universal dictionary of arts, sciences, and literature 14, London. Ficus no. 1-105.

Sprengel, C. (1817) Systema Vegetabilium 2. Stuttgardtiae, 964 pp.

Srivastava, T.N. (1976) Flora Gorakhpurensis. Today \& Tomorrow's Printers and Publishers, Delhi, India, 411 pp.

Thiers, B. (2012) Index Herbariorum: A global directory of public herbaria and associated staff. New York Botanical Gardens' Virtual Herbarium. <http://sweetgum.nybg.org/ih/>.

Willdenow, C.L. (1806) Species Plantarum 4 (2). Berlin, pp. 633-1157. 